\title{
EXPLORING THE IMPORTANCE OF EMOTIONS WITHIN CONSUMER BEHAVIOUR ON THE CZECH LUXURY COSMETIC MARKET
}

\author{
Dorota Anderlová1 ${ }^{1}$ Michal Pšurný ${ }^{1}$ \\ ${ }^{1}$ Department of Marketing and Trade, Faculty of Business and Economics, Mendel University in Brno, \\ Zemědělská 1, 61300 Brno, Czech Republic
}

Link to this article: https://doi.org/10.11118/actaun202068020363

Received: 20. 12. 2019, Accepted: 15. 4. 2020

To cite this article: ANDERLOVÁ DOROTA, PŠURNÝ MICHAL. 2020. Exploring the Importance of Emotions Within Consumer Behaviour on the Czech Luxury Cosmetic Market. Acta Universitatis Agriculturae et Silviculturae Mendelianae Brunensis, 68(2): 363-372.

\begin{abstract}
In the last few decades, the role of emotions has been gaining importance across all industries when examining consumer's behavioural decisions. The impact that the emotions have on judgments, evaluations and decisions has long been important not only to psychology, but also to economic sciences. This paper aims to investigate the attitudes and behaviour of Czech women in regards to purchasing, using and their overall attitude to skincare products in the luxury segment, with special focus on emotions and social status as an influential factor. A targeted questionnaire was applied as a base to gain relevant quantitative data. Quantitative data were collected from 782 cosmetics consumers in luxury perfumeries all over the Czech Republic. Data were evaluated by means of descriptive statistics, dependencies were expressed by contingency (Chi-Square Test) and customer segmentation was managed by cluster analysis (k-means method, Euclidian distance). The obtained data clearly shows the significant importance of emotions and social value to certain female consumer segments. The research results provided valuable insights and information for the producers, marketers and managers to understand consumer attitudes, behaviour and social trends in the skincare cosmetics perfumery market and will help them to develop products, marketing and business strategies that are tailor-made to actual consumer needs and desires.
\end{abstract}

Keywords: emotions, consumer behaviour, segmentation, skincare, influencing factors, luxury, cosmetics

\section{INTRODUCTION}

The success of all organisations lies in the hands of the consumers. Their needs, wishes and buying behaviour must be understood. Consumer behaviour during a purchase is defined as an analysis of when, where, how and why people buy a certain product. Each human being is different and each consumer decision process is affected by many different factors. Also rapid and constant change in consuming trends and habits put retailers under high pressure to satisfy their consumers. Emotions, as an influencing factor have been discussed since quite a long time and their importance when coming to consumer behaviour cannot be over looked as it is definitely relevant to many industries.

After a long period of time, in which under the influence of economic theories consumers were predicted to make predominantly rational decisions based on the product's utility, attributes and benefits, over the past few decades marketing experts have begun to study the emotions that are induced by marketing incentives, products and brands. This paper focuses on the role of emotions and to a certain extent social status in 
luxury skincare cosmetics segments specifically targeted to the female consumer and reveals some specifics connected to various consumer segments. Understanding of consumer decision process is one of the key success of marketing strategies for those who aim to be successful, effective and profitable. Marketers, sellers and producers worldwide are searching the most effective marketing approaches to influence the final consumer decision. The paper offers new learnings regards addressing consumers within skincare luxury segment with respect to selected influencing factors. The crucial question is whether the influence of emotions on consumer purchasing decisions is equally relevant for all luxury products industries and for all consumer segments, or is the perception of this factor different for different types of products and various consumers segments diverse by age, income, gender, etc. This paper is assessing emotions and their impact on consumer behavior in the luxury skin cosmetics market in the Czech market. The main aim is to identify and analyze consumer segments that are significantly affected by emotions and to bring new findings for entities operating in this industry, with focus on specific view of consumer behavior through the emotions as an influencing factor in the purchasing decisionmaking process.

Instead of focusing on how theoretical and often highly unrealistic consumers could make a decision, marketers have increasingly redirected their focus to analysis based on how real people truly act. Such an analyses of behavioural economics seeks to improve the predictive power of economics by improving its basic model of human behaviour.

The consumer has generally been depicted as a rational person who possesses immense foresight and cognitive abilities, but at the same time is devoid of emotions (Lee, 2009). By the mid-20 ${ }^{\text {th }}$ century, the assumption of unlimited human rationality was being questioned by several psychologists who highlighted the influence of subjective considerations in the decision-making process (Simon, 1961). Tversky and Kahneman (1974) examined certain phenomena present in economic agents' decisions such as anchoring, availability and overconfidence. It was discovered that people not only follow the rules of mathematical logic, but also use a variety of intuitive procedures and mental abbreviations. Therefore, the main focus of behavioural economics has been on how people evaluate economic opportunities and how they appreciate the benefits of alternative choices (Friedman et al., 1994). A number of studies have emphasized that consumers are immersed in their social context, and their thinking and emotion could be partly due to social influences (Rychalski and Palmer, 2017) but can also be influenced by their knowledge, previous attitudes, personality traits (Yu, 2017) and other variables.

\section{Emotions and Consumer Behaviour}

There are many different ways of defining the emotions. However, scientists mostly agree that emotions are understood as the reaction of the body to external or internal stimulus. They are perceptions of bodily changes to certain stimulus. When these perceptions are conscious, we can also say emotions that are feelings (Prinz, 2005). From the above points, we can say that all feelings are emotions, although not all emotions are feelings. They are basically physiological reactions, which means that they have a significant impact on people's well-being, physical health, social functioning and our problemsolving performance, therefore understanding the emotions should be a major agenda for the social and biological sciences (Lazarus, 1991). Nowadays, it is obvious that emotions (Williams, 2014), such as motivation (Martin et al., 1993) or cognitive appraisals (Lerner, Han and Keltner, 2007; Roseman and Evdokas, 2004) have an impact on consumption or consumer choice. (Kagita, 2018; Bettiga, 2018; Mohammed, 2019). Kagita (2018) showed that emotions play a key role in purchase intention in his experiment. Curtis et al. (2017) added judgment into the relation between emotions and consumer behaviour and showed that judgment partially mediates the relationship between consumers' emotions and purchase decision and that positive emotional reaction is directly and positively related to purchase intent. Also study from Ostrovskiy (2019) showed that emotion itself pervasively affects all affective consumer decisions.

All the definitions of emotions also agree that they can vary by valence. Emotions can be positive, negative or mixed (Williams, 2014). There are studies (e.g. Di Muro, 2012) that suggest that people make consumption choices that are consistent with maintaining positive moods and mitigating negative affective states. Different mood triggers might give rise to specific cognitive and motivational processes that then influence the decisions that consumers ultimately make. For example, evidence suggests that decreases in negative affect can increase consumers' willingness to pay for a variety of products (Murray et al., 2010). Emotions may also influence willingness to pay and price sensitivity (Williams, 2014).

However, the impact of emotions on judgments, evaluations and decisions is significant to consumer behaviour. There are studies that demonstrate that emotions, like cognitions, have an impact on consumption (Damasio, 1994; Loewenstein, 2004). It is important to understand what drives the experience of emotional states, how those emotions uniquely affect decision making and the motivation that consumers might have. We can study emotions that are more hedonic (through the arousal measurement for example) but also those that rely on higher order self-conscious processes to arise (Williams, 2014). This paper is focused on the second category through a targeted survey. 
Nowadays, cognitive processes remain to be associated with rationality and right decisions, while emotional processes are irrational. However, this view is outdated. There are several studies (Kahneman, 2012; Lee, 2009) that contradict this view. Some aspects that are generally understood as rational are generated by the emotional system (Lee, 2009). Conversely, errors in decision making are associated with cognitive processes and heuristicams (Tversky, 1974; Kahneman, 2012).

Emotional status can also strongly influence impulsive purchase how they showed in a study from Bessouh and Belkhir (2018) or Song et al. (2019).

\section{Emotions Towards Luxury Skincare Products}

A critical element of marketing is the assessment of consumer preferences. Traditionally, preferences are measured using psychological indices such as evaluation, semantic differential scales and joint analysis (Netzer et al., 2008). In general, it is complex to use psychological and behavioural indexes to measure product preferences with high consumer interest, although a relatively small difference between products in terms of performance and quality. That is because product preferences are not only determined by cognitive processes, but also by affective and intuitive product responses (Bagozzi et al., 1999). Surely it can be stated that cosmetic products are such kind of products. Attitude toward skincare cosmetics is an emotional appreciation based on pleasure and attraction (Tajeddini, 2014). There are certain studies that study factors influencing the buying behaviour of skincare products (e.g. Koshy, 2017) although there are none that deal with emotional factors.

\section{Consumer Behaviour in the Luxury Segment}

This paper focuses on consumer behaviour in the luxury cosmetics segment as a consumer segment with its particular specifics. Although the majority of consumers purchase their cosmetic products in drugstores and supermarkets, there is a special class of cosmetics for those who want the luxury experience when it comes to makeup and skincare brands.

The market for luxurious and prestigious cosmetics is evaluated at 116 billion U.S. dollars in 2017 and has an expected growth of about 126 billion dollars by 2019. The majority of the sales value of prestige cosmetics generate premium skincare products (Shahbandeh, 2019). Skin care category has been steadily growing since 2012, and is predicted to keep this trend at least until 2024. The segment of premium - prestige skin care principally includes skin creams and lotions for face and body care, lip care products as well as hand and foot care products. This overall market definition is broadly aligned, while here only the premium price range is considered. Professional products produced for cosmetic parlours are not included nor are beauty services (Shahbandeh, 2019).
Despite various research on luxury goods consumption, there is still no uniform definition of luxury goods (Amatulli et al., 2015; Vigneron, 2017). Luxury products are often the ones with the highest price and quality, provide the consumer with an outstanding experience or sense of prestige and evoke perceptions of rarity, privilege, and an exceptional life (Rolling and Sadachar, 2017). A study by Semaan (2019) suggests that these are products that excel among others and confer some prestige to consumers and status in society. Research has also shown that there may be different degrees of luxury based, for example, on material or design. In this study, they identify drivers of luxury consumption. These drivers are the need for unique emotions, selfeastern, empowerment, status, need for conformity, self-consciousness, and social context.

In economics, luxury products are considered to be rare and expensive with a strong positive income demand elasticity, in contrast to necessity goods: increased income results in a larger demand for luxury goods in general (Holman, 2007). Despite a significant price influence, is there any stimuli driving the consumer's luxury consumption? Surely, some factors can be desire and the pleasure that luxury goods evoke, for instance (Kemp, 1998), and so the value of luxury brands and their perception are often associated with luxury brand consumption (Vigneron and Johnson, 2004). Moreover, a social prestige status, as a symbol, plays a key role in luxury brand consumption (Vigneron and Johnson, 1999).

Vigneron and Johnson (1999) explain luxury consumption according to the five effects. The Veblen effect - perceived conspicuous value. These consumers perceive price as an indicator of prestige because their primary objective is to impress others. The elitist effect - perceived unique value. These consumers perceive price as an indicator of exclusivity and they avoid using popular brands. The bandwagon effect - perceived social value. Relative to elitist consumers, bandwagon consumers attach less importance to price as an indicator of prestige, although they will place greater emphasis on the effect they make on others while consuming prestige brands. The hedonic effect - perceived emotional value. Hedonist consumers are more interested in their own thoughts and feelings, and thus will place less emphasis on price as an indicator of prestige. The perfectionism effect - perceived quality value.

Husic and Cicic (2009) discovered unexplained variance left in their research, which indicates hedonistic behaviour in the luxury segment. They grouped luxury consumption into four categories: brand image and quality, fashion, store atmosphere and patron status. However, they also state that certain areas are not covered by those factors and they state that hedonism and other psychographic characteristics need to be explored. They found that consumers try to treat themselves with a luxury product and to enjoy it for own sake, rather than to impress other people. 
Husic and Cicic (2009) also showed that luxury consumers come from different social classes and have different incomes. However, income or money is a necessity for luxury consumption. An interesting finding is also that luxury consumers in Bosnia and Herzegovina do not differ from consumers in France, Russia or Australia.

Tian et al. (2001) identified that consumers pursue uniqueness because they want to develop and enhance their self-image and social status. This finding enriched the research about consumption of luxury products and the symbolic meaning of luxury products (Tak and Pareek, 2016). Study by Chen (2016) showed that consumers in the luxury segment are price sensitive and they make comparisons between different retailers, although they are willing to pay the high price of luxury brands because of the brand image and prestige.

The study from Kuo et al. (2020) showed when the consumers identify the brand as a luxury brand then it establishing consumer trust, which leads to consumer purchase intention. A better degree of consumer trust accelerates consumers' intention to purchase brand products.

\section{MATERIALS AND METHODS}

The research method to collect primary data was a structured questionnaire. The questionnaire was the main research instrument, along with face-toface interviews with the respondents, marketers and managers from the cosmetic industry in order to clarify the questions and capture additional insights beforehand. The questions were adapted according to the usage and purchase of skincare products and its specifics to consumer behaviour. Specific factors connected to skincare products were implemented - ingredients efficiency, natural ingredients, product sampling and consultancy, emotional and social factors.

The research tool was a standardised survey sent by email within customer's newsletter communication to a consumer database provided by a local Czech perfumery chain called FAnn perfumery. Additionally, a pop-up banner was placed on the FAnn perfumeries website for the period of two weeks. The questionnaire was only sent to consumers who regularly and repeatedly bought luxury skincare products, therefore with previous experience and knowledge of relevant products. The research was completed in January 2019 and collected feedback from total 782 respondents. The research sample involved 779 women and only three men, accounting for $99.6 \%$ and $0.4 \%$ of the sample, as the survey was targeted to a certain consumer group - regular luxury skincare cosmetics users. Analysing the demographics data of the research sample, most of consumers have secondary education (47.8\%) or a university degree $(41.8 \%)$ and the place of residence containing over 100,000 inhabitants covered $41.8 \%$ of the survey sample. The monthly net income per person in the respondents' households usually ranged from 801 to $€ 1,200$, as $39.5 \%$ of the respondents provided such answers. Altogether 388 women (49.6\%) declared their family status as married and $71.9 \%$ stated their economic activity as employed. More details are provided in Tab. I.

The above described demographic identification provides a customer profile of female luxury cosmetic segment in skincare products on Czech market. Being presented by an employed woman (monthly net income around $€ 2,000$, mostly in age 35-54, with secondary or university education and living in a large cities.

The questionnaire was composed from general defining factors influencing skincare cosmetics consumer behaviour with focus on brand value, type of advertising. Separate part was dedicated only to natural skincare products and emotional factors plus social status. Before placing these specific questions regarding emotional factors and social status connected to skincare products consumption, a general question was asked in order to define the specific consumer group being influenced by emotions. In order to let the respondents to clearly understand the meanings, a brief explanation of the terms preceded this filtering question, with an explanation of the emotions associated with the purchase and usage of skincare cosmetics and the notion of social status its context within this product segment. The question is as follows:

\section{Do you connect buying and using skincare products with EMOTIONS?}

505 respondents (64.6\%) stated YES, while 277 respondents (35.4\%) stated NO. This feedback illustrates first impression regards connection of emotions and skincare products consumption. Following that, a total of eight questions were asked regarding emotional factors and social status, presented only to the group of 505 respondents (Tab. II)

The participants responded to the statements using a 10-point Likert scale, where a score of 1 meant "I strongly disagree" and a score of 10 meant "I strongly agree". Two particular questions (No. 8 and No. 9) were connected to social status. The rest of the given questions, seven in total, were meant to express emotions and feelings.

Cluster analysis as multi-dimensional analysis was carried out to identify the main consumer segments of the luxury skincare cosmetics market. The cluster analysis divides the research sample into several groups so that the objects in the file are as similar as possible to the clustered group. The first step was to encode data and to adapt the criteria to appropriate scales. The clustering method was based on the k-means method and the Euclidean distance was used as the distance from the centroid. The data were sorted into clusters based on their attributes. 
I: Characteristics of the research sample $(n=782)$

\begin{tabular}{|c|c|c|c|}
\hline Specification & & Absolute Number & Percentage of Tested Sample \\
\hline \multirow{2}{*}{ Gender } & Female & 779 & $99.6 \%$ \\
\hline & Male & 3 & $0.4 \%$ \\
\hline \multirow{5}{*}{ Age } & $18-24$ & 36 & $4.6 \%$ \\
\hline & $25-34$ & 124 & $15.9 \%$ \\
\hline & $35-44$ & 203 & $26 \%$ \\
\hline & $45-54$ & 225 & $28.8 \%$ \\
\hline & 55 and more & 194 & $24.8 \%$ \\
\hline \multirow{4}{*}{ Education } & Primary & 7 & $0.9 \%$ \\
\hline & Lower secondary school & 74 & $9.5 \%$ \\
\hline & Secondary school & 374 & $47.8 \%$ \\
\hline & University degree & 327 & $41.8 \%$ \\
\hline \multirow{5}{*}{ Monthly Net Income } & Lower than $€ 600$ & 120 & $15.3 \%$ \\
\hline & From $€ 601$ to $€ 800$ & 172 & $22 \%$ \\
\hline & From $€ 801$ to $€ 1,200$ & 309 & $39.5 \%$ \\
\hline & From $€ 1,201$ to $€ 2,000$ & 143 & $18.3 \%$ \\
\hline & More than $€ 2,000$ & 38 & $4.9 \%$ \\
\hline \multirow{4}{*}{ Family Status } & Single & 226 & $28.9 \%$ \\
\hline & Married & 388 & $49.6 \%$ \\
\hline & Divorced & 143 & $18.3 \%$ \\
\hline & Widowed & 25 & $3.2 \%$ \\
\hline \multirow{6}{*}{ Economic Activity } & Employed & 562 & $71.9 \%$ \\
\hline & Self-employed & 66 & $8.4 \%$ \\
\hline & Unemployed & 12 & $1.5 \%$ \\
\hline & Retired & 84 & $10.7 \%$ \\
\hline & Student & 31 & $4 \%$ \\
\hline & Maternity leave & 27 & $3.5 \%$ \\
\hline \multirow{6}{*}{ Place of residence } & Less than 2000 inhabitants & 98 & $12.5 \%$ \\
\hline & 2,001-5,000 inhabitants & 63 & $8.1 \%$ \\
\hline & 5,001-10,000 inhabitants & 63 & $8.1 \%$ \\
\hline & 10,001-50,000 inhabitants & 138 & $17.6 \%$ \\
\hline & $50,001-100,000$ inhabitants & 93 & $11.9 \%$ \\
\hline & More than 100,000 inhabitants & 327 & $41.8 \%$ \\
\hline
\end{tabular}

Furthermore, the selection of the initial sample points is necessary which will be randomly selected from the input set of objects. The individual objects were assigned to the nearest sample point until stable decomposition is achieved. In analysing, it is necessary to define the criteria that have a significant impact, as the number of clustering variables can affect segment homogeneity. Those criteria were selected where the respondents have the most answers. In addition, questions that have a significant impact on clusters were defined. Subsequently, an analysis of the interdependence between the individual criteria were carried out in order to avoid misallocation of the disproportionate meaning of any variable. The description of segments was based on cross tables, which were created using the IBM SPSS Statistics program.

Due to low answer frequencies, the following questions were not included into cluster analyses: consumers aged 18-24, basic education, incomes over €2,000, widowed, unemployed, economic activity students and women on maternity leave. Also answers with the indication "I do not buy skincare products" and gender category - male gender 


\section{II: Emotions and social status}

\begin{tabular}{rl|l}
\hline & \multicolumn{2}{c}{ Emotions and social status } \\
\hline 1 & $\begin{array}{l}\text { Buying and using skin care cosmetic products } \\
\text { brings me pleasure. }\end{array}$ \\
\hline 2 & I love taking care of my skin. \\
\hline 3 & $\begin{array}{l}\text { Thanks to cosmetic products I feel good about } \\
\text { myself. }\end{array}$ \\
\hline 4 & I look forward to my skin care cream every day. \\
\hline 5 & By using a cosmetic product I feel younger. \\
\hline 6 & The appearance of my skin is important to me. \\
\hline 7 & $\begin{array}{l}\text { Healthy and youthful skin increases my } \\
\text { self-confidence. }\end{array}$ \\
\hline 8 & $\begin{array}{l}\text { The usage of skin care products increases my social } \\
\text { prestige. }\end{array}$ \\
\hline 9 & $\begin{array}{l}\text { The good appearance of my skin increases my } \\
\text { social status. }\end{array}$ \\
\hline
\end{tabular}

(only three respondents) were excluded from the research sample. Therefore, the final number of the research sample was 385 respondents and cluster analyses led to the selection of two segments. As the next step, names were given to the isolated segments which, in the opinion of the authors, best reflected the behavioural habits in each cluster in the luxury skincare cosmetics market.

Larger cluster 1 representing 52.7\% was named "Emotional, frequent user, loyal and socially connected" and smaller cluster 2 with a share of $47.3 \%$ gain a name "Novelty lover, not brand and not emotionally influenced”.

\section{RESULTS}

As the first step, the collected data were tested on dependencies via pivot tables that express the relationship between the variables. Dependencies were tested using a Pearson chi-square test where the significance level is determined at $5 \%$. Dependency was measured in correlation with AGE and the statement "Buying and using skincare cosmetics products brings me a pleasure" with p-value at 0.00711 and Pearson chi-squire 54.90081 which clearly show the dependency of age and emotions in which age group 35-44 years old represented 28\% and age group 45-44 years represented $29 \%$ on total (Tab. III).

The importance of social status connected to usage of skincare products also revealed contingency vs. AGE. Statement "The usage of skincare products increases my social prestige" counted p-value at 0.04726 and Pearson chi-squire 51.28888 in which

III: Chi-square test Buying and using skin care cosmetics products brings me a pleasure vs. age

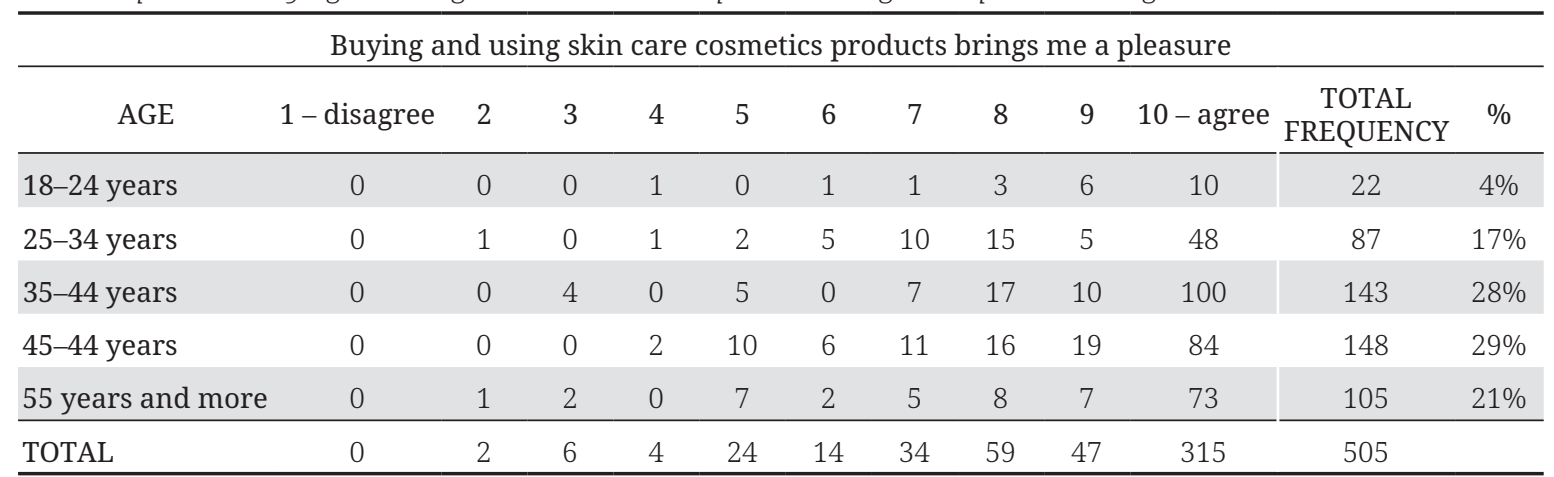

p-value 0.00711

Pearson chi-square 54.90081

IV: Chi-square test The usage of skin care products increases my social prestige vs. age

The usage of skin care products increases my social prestige

\begin{tabular}{|c|c|c|c|c|c|c|c|c|c|c|c|c|}
\hline AGE & 1 - disagree & 2 & 3 & 4 & 5 & 6 & 7 & 8 & 9 & 10 - agree & $\begin{array}{c}\text { TOTAL } \\
\text { FREQUENCY }\end{array}$ & $\%$ \\
\hline $18-24$ years & 6 & 2 & 1 & 2 & 1 & 2 & 1 & 4 & 0 & 3 & 22 & $4 \%$ \\
\hline 25-34 years & 22 & 6 & 11 & 8 & 11 & 11 & 4 & 2 & 3 & 9 & 87 & $17 \%$ \\
\hline $35-44$ years & 44 & 7 & 8 & 4 & 19 & 12 & 16 & 7 & 3 & 23 & 143 & $28 \%$ \\
\hline 55 years and more & 18 & 9 & 3 & 4 & 18 & 8 & 9 & 11 & 5 & 20 & 105 & $21 \%$ \\
\hline TOTAL & 125 & 36 & 35 & 24 & 74 & 53 & 35 & 34 & 19 & 70 & 505 & \\
\hline
\end{tabular}

p-value 0.04726

Pearson chi-square 51.28888 


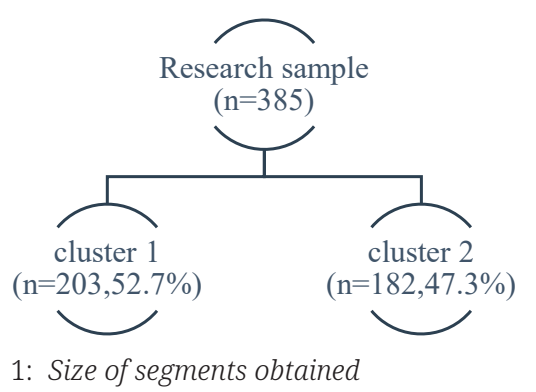

again age group 35-44 years old represented 28\% and age group 45-44years represented 29\% on total (Tab. IV).

As already anticipated above the cluster analyses led into a selection of two consumer clusters. The size of the segments is shown in Fig. 1.

\section{Cluster 1}

Cluster 1 included consumers purchasing facial products monthly (64.9\%) and using not only facial skincare products but also body cosmetics (62.1\%). it is worth mentioning that 39\% of consumers in this cluster are more willing to spend money on facial skincare, in between $€ 50$ to $€ 200$ per one product. Therefore, the brand name is highly important, reaching $43 \%$ of cluster consumers. This cluster is quite conservative as their interest for novelties declared only $12 \%$, on the other hand $87 \%$ would buy products based on a previous satisfactory experience, so $62 \%$ based their satisfactory experience of the products bearing the same brand name. Taking into consideration a fairly high income level, the price sensitivity of this cluster is surprisingly intense reaching $45 \%$ of the given answers declaring their interest in special price discounts. Coming to the theme of emotions we can consider this cluster to be more emotional as $52.7 \%$ of sample answered "yes" to the question "Do you connect buying and using of skincare products with EMOTIONS?” In confirmation of that, $72.5 \%$ confirmed expecting emotional pleasure when purchasing skincare products, as $72.8 \%$ love taking care of their skin. Consequently, more than $80 \%$ confirm that using skincare products brings real personal pleasure, and every day they look forward to applying their facial cream as it brings positive feelings and awesome personal experience. This cluster also declares the importance of social status as $80 \%$ confirms that social prestige and social status in connection with skincare product usage. This segment was characterised by women aged 35-44 years old (33\%), almost half of the consumers who made up this segment have income from $€ 1,200$ to 2,000, having secondary education (50\%), being employed (75\%) and married (55\%) and having 38\% their residence in cities over 100,000 inhabitants. Therefore, the cluster can be described as "Emotional, frequent user, loyal and socially connected".

\section{Cluster 2}

Consumers forming the second segment (cluster 2), do not use facial skincare products as frequently, as 60\% declared that they purchase these products only once a quarter and their willingness to spent an amount on one product is lower compared to cluster 1, as 40\% would spent only $€ 20$ to $€ 40$ per product. There is no significant attitude to brand equity as only $10 \%$ of the cluster respondents would classify brand awareness as a strong influencing factor when making purchase decisions regarding skincare products and 32\% would purchase a product based on their own satisfactory experience from the same brand. In connection with this they are quite eager to search for novelties and trends on beauty blogs and new internet pages (53\%). Their interest in price discounts or special offers can be measured at $7 \%$ of the declared answers, so their price sensitivity appears to be extremely low. Focusing more closely on emotions, this cluster does not connect emotions with skincare products significantly. Only 27.5\% admit to perceiving pleasure from using skincare products, so $27 \%$ enjoys taking care of their skin. Totally $12.9 \%$ look forward to purchasing and using their facial skincare. In addition, the overall approach to social importance is much lower than within cluster 1. Surprisingly, 3.4\% consider social prestige to be increase by the use of skincare products and 19.1\% agree with the overall delivered social level. This cluster was formed by women aged $45-54$ years old (63\%). Nearly half (44\%) of the participants in this segment have an income ranging from $€ 1,200$ to 2,000 and gained university level education (51\%), being employed (76\%) and married (55\%) and 45\% live in cities with over 100,000 inhabitants. Based on the above mentioned statistics, the cluster could be described as "Novelty lovers, not brand or emotionally influenced”.

\section{DISCUSSION}

As anticipated above, the research was conducted on a certain consumer type, specifically consumers in the luxury brand environment with knowledge and previous usage of skincare cosmetics products. Via the cluster analyses method only two different cluster segments were created, which means that we can state that this research sample was very homogenous. The two clusters overall differed, although not significantly in all attributes.

The importance of emotions and social prestige is substantial the same as Kagita (2018) showed. Consumers from the first cluster love their brands, although they are shrewd regarding their investments and wait for advantageous price offers. This segment basically coincides with the results achieved by Chen et al. (2016). The main age group varies from 35-45 years and their income ranges from $€ 1,200$ to 2,000 . Conversely, the smaller 
cluster 2 does not regard emotions and social status so highly. Respondents are eager for novelties and trends without significant price sensitivity.

The second cluster, compared to cluster 1, is slightly older (45-54 years old) and has a higher level of education (university degree). Some attributes are the same for both clusters, such as the level of income ( $€ 1,200$ to 2,000 ), economic activity (employed), family status (married) and living in cities over with 100,000 inhabitants, which we can interpret as being concrete specifics for the luxury segment description.

The limitation of this research can be seen in analysing only the specific luxury consumer segment and emitting other types of consumers, therefore the results cannot be applied to the entire Czech market and therefore cannot be considered to be fully representative. However, according to the author's opinion, the presented results may provide interesting insights regards consumer behaviour in the skincare cosmetics market with focus on emotions and social status. Despite of this, another survey needs to take place in order to gain relevant and applicable data reaching a younger target group, lower income population and people living in smaller towns with economic activity other than employment. As a following step, consumers from a drugstore chain will be surveyed with the same aim to receive additional insight regarding consumer purchasing behaviour with a deeper focus on emotions and the importance of social status.

This research also studied what Husic and Cicic (2009) called hedonistic behaviour in the luxury segment. The results indicate that the connection of the respondents to emotions and social status in the cosmetics industry are an important factor to certain consumer types and it is following the trend of other industries and businesses. The importance of emotions supports the study from Kagita (2018) and Battiga (2018) which showed that emotions play a key role in making a brand choice and of purchase intention. It also confirms to the findings of Damasio (1994) or Loewenstein (2004) in terms of emotions and Tian et al. (2001) in terms of social status. Not only the emotions and their importance, but also social prestige is relevant. As the study from Semaan (2019) showed that self-esteem is an important emotionally-based driver for luxury consumption. Therefore, the importance cannot be overlooked and these factors should be considered as consumers prioritize them when making a final purchasing decision in the skincare product category.

\section{CONCLUSION}

However, it needs to be taken into account that emotional connection and social prestige is not as relevant to all consumers at the same level, although it has higher importance to concrete consumers segment characterised by age, income or education level. Concretely the group between 35-45 years old with income, employed, living in big cities with more than 100,000 inhabitants with an income reaching $€ 1,200$ to $€ 2,000$ are more emotionally conscious and social prestige is more important to them. From the practical perspective, it confirms to producers, sellers and marketers the existence of the emotional and social consumer segment within skincare cosmetics industry, therefore they can actively work on products and strategies based on this knowledge, which may be the source of competitive advantage for companies indicated, for example, in Houman and Kumar (2005).

Result of this research can be effectively used when planning specific marketing activities to support the luxury skincare business. Taking into consideration also the fact that skincare products, especially facial skincare products, are by their purpose and composition typically products that are intended for specific consumer differed primarily by age and skin type. Therefore targeted consumer segmentation is crucial part of the overall marketing strategy in skincare product segment. As already mentioned above, each consumer is different, influenced more or less by different factors. The research offers two different consumers clusters with different influencing factors. Concretely the specific segment - cluster 1 revealed in the study, deserve attention in terms of adjusting marketing communications towards advertising claims that stimulate emotions using words such as: love, joy and pleasure. Further also mentioning brand name with emphasizing social status can be very efficient marketing strategy for this specific cluster.

\section{Acknowledgements}

This paper is the result of a research project supported by the Faculty of Business and Economics, MENDELU, developed and funded under the IGA (Interní grantová agentura PEF) project No. PEF_DP_2019001, named "Rozhodovací nákupní proces vybrané genderově vázané kategorie”. 


\section{REFERENCES}

Amatulli, C., Guido, G., Mileti, A., TOMACElli, C., PRETE, M. I. and LONGO, A. E. 2015. "Mix-and-Match" Fashion Trend and Luxury Brand Recognition: An Empirical Test Using Eyetracking. Fashion Theory, 20(3): 341-362.

ANDERSEN, P. H. and KUMAR, R. 2006. Emotions, trust and relationship development in business relationships: A conceptual model for buyer-seller dyads. Industrial Marketing Management, 35(4): 522-535.

BAGOZZI, R. P., GOPINATH, M. and NYER, P. U. 1999. The role of emotions in marketing. Journal of the Academy of Marketing Science, 27(2): 184-206.

BESSOUH, N. and BELKHIR, D. O. 2018. The Effect of Mood on Impulse Buying Behavior - Case of Algerian Buyers. Austin J. Bus. Adm. Manage., 2(1): 1023.

BETTIGA, D. and LAMBERTI, L. 2020. Exploring the role of anticipated emotions in product adoption and usage. Journal of Consumer Marketing, 35(3): 300-316.

CURTIS, T., ARNAUD, A. and WAGUESPACK, B. P. 2017. Advertising Effect on Consumer Emotions, Judgements, and Purchase Intent. Asian Journal of Business Research, 7(2): 57-73.

DAMASIO, A. R. 1994. Descartes' error: emotion, reason, and the human brain. New York: Putnam.

DI MURO, F. and MURRAY, K. B. 2012. An Arousal Regulation Explanation of Mood Effects on Consumer Choice. Journal of Consumer Research, 39(3): 574-584.

FRIEDMAN, D. and SUNDER, S. 1994. Experimental Methods: A Primer for economists. New York: Cambridge University Press.

HAN, S., LERNER, J. S. and KELTNER, D. 2007. Feelings and Consumer Decision Making: The AppraisalTendency Framework. Journal of Consumer Psychology, 17(3): 158-168.

HOLMAN, R. 2007. Microecomics: intermediate course [in Czech: Mikroekonomie: středně pokročilý kurz. 2]. Beckovy ekonomické učebnice. Praha: C. H. Beck.

HUSIC, M. and CICIC, M. 2009. Luxury consumption factors. Journal of Fashion Marketing and Management: An International Journal, 13(2): 231-245.

CHEN, H., ZHOU, J. and YU, J. 2016. consumer perception and consumption behavior regarding luxury products in the fashion industry. International Journal of Business, Marketing \& Decision Science, 9(1): 84-96.

KAGITA, N. 2018. Role of emotions in the FMCG branding and their purchase intentions. Vidwat: The Indian Journal of Management, 11: 24-28.

KAHNEMAN, D. and FREDERICK, S. 2012. Representativeness Revisited: Attribute Substitution in Intuitive Judgment. In: GILOVICH, T., GRIFFIN, D. and KAHNEMAN, D. (Eds.). Heuristics and Biases. Cambridge University Press, pp. 49-81.

KEMP, S. 1998. Perceiving luxury and necessity. Journal of Economic Psychology, 19(5): 591-606.

KOSHY, L. and MANOHAR, J. 2017. Factors influencing the buying behaviour of face care products among youth. International Journal in Management and Social Science, 5(1): 63-72.

KUO, C. and NAGASAWA, S. 2020. Deciphering Luxury Consumption Behavior from Knowledge Perspectives. Journal of Business, 26(1): 1-21.

LAZARUS, R. S. 1982. Thoughts on the relations between emotion and cognition. American Psychologist, 37(9): 1019-1024.

LAZARUS, R. S. 1991. Cognition and motivation in emotion. American Psychologist, 46(4): 352-367.

LEE, L., AMIR, O. and ARIELY, D. 2009. In Search of Homo Economicus: Preference Consistency, Emotions, and Cognition. Journal of Consumer Research, 36(2): 173-187.

LOEWENSTEIN, G. F. and O'DONOGHUE, T. 2004. Animal Spirits: Affective and Deliberative Processes in Economic Behavior. CAE Working Paper \#04-14. Cornell University, Center for Analytic Economics.

MARTIN, L. L., WARD, D. W., ACHEE, J. W. and WYER, R. S. 1993. Mood as input: People have to interpret the motivational implications of their moods. Journal of Personality and Social Psychology, 64(3): 317-326.

MOHAMMED, A. J. and NEETHULAL, V. 2019: Perceived effectiveness of advertisements: The role of emotions. Indian Journal of Health, 10(7-9): 271-275.

MURRAY, K. B., DI MURO, F., FINN, A. and POPKOWSKI LESZCZYC, P. 2010. The effect of weather on consumer spending. Journal of Retailing and Consumer Services, 17(6): 512-520.

NETZER, O., TOUBIA, O., BRADLOW, E. T., DAHAN, E., EVGENIOU, T., FEINBERG, F. M. et al. 2008. Beyond conjoint analysis: advances in preference measurement. Mark. Lett., 19: 337-354.

OSTROVSKIY, A., GARKAVENKO, V. and RYBINA, L. 2019. Influence of socio-psychological factors on consumers purchasing behavior in Kazakhstan. The Service Industries Journal, DOI: 10.1080/02642069.2019.1601707.

PRINZ, J. 2005. Are emotions feelings? Journal of Consciousness Studies, 12(8-10): 9-25. 
ROLLING, V. and SADACHAR, A. 2017. Are sustainable luxury goods a paradox for millennials? Soc. Responsib. J., 14(4): 802-815.

ROSEMAN, I. and EVDOKAS, A. 2004. Appraisals cause experienced emotions: Experimental evidence. Cognition \& Emotion, 18(1): 1-28.

RYCHALSKI, A. and PALMER, A. 2017. Customer Satisfaction and Emotion in the Call Centre Context. In: The Customer Is NOT Always Right? Marketing Orientations in a Dynamic Business World. Springer: Cham, Switzerland, pp. 67-70.

SEMAAN, R. W., LINDSAY, V., WILLIAMS, P. and ASHILL, N. 2019. The influence of gender roles in the drivers of luxury consumption for women: Insights from the gulf region. Journal of Retailing and Consumer Services, 51: 165-175.

SEO, Y. and BUCHANAN-OLIVER, M. 2019. Constructing a typology of luxury brand consumption practices. Journal of Business Research, 99: 414-421.

SIMON, H. A. 1961. Administrative Behavior. New York: The Macmillan Company.

SONG, J. and QU, H. 2019. How does consumer regulatory focus impact perceived value and consumption emotions? International Journal of Contemporary Hospitality Management, 31(1): 285-308.

SHAHBANDEH, M. 2019. Prestige/Luxury Cosmetics Industry - Statistics \& Facts. Statista. [Online]. Available at: https://www.statista.com/topics/5073/prestige-luxury-cosmetics/ [Accessed: 2019, June 12].

TAJEDDINI, K. and NIKDAVOODI, J. N. 2014. Cosmetic buying behavior: examining the effective factors. Journal of Global Scholars of Marketing Science, 24(4): 395-410.

TAK, P. and PAREEK, A. 2016. Consumer attitude towards luxury brands: An empirical study. Journal of Brand Management, 13(1): 7-19.

TIAN, K. T., BEARDEN, W. O. and HUNTER, G. L., 2001. Consumers' Need for Uniqueness: Scale Development and Validation. Journal of Consumer Research, 28(1): 50-66.

TVERSKY, A. and KAHNEMAN, D. 1974. Judgment under Uncertainty: Heuristics and Biases. Science, 185(4157): 1124-1131.

VIGNERON, F. and JOHNSON, L. W. 1999. A review and a conceptual framework of prestige seeking consumer behavior. Academy of Marketing Science Review, 1(1): 1-15.

VIGNERON, F. and JOHNSON, L. W. 2004. Measuring perceptions of brand luxury. Journal of Brand Management, 11(6): 484-506.

WILLIAMS, P. 2014. Emotions and Consumer Behavior. Journal of Consumer Research, 40(5): viii-xi.

VIGNERON, F. and JOHNSON, L. W. 2017. Measuring Perceptions of Brand Luxury. In: KAPFERER, J.-N., KERNSTOCK, J., BREXENDORF, T. O. and M. POWELL, S. M. (Eds.). Advances in Luxury Brand Management. Cham: Springer International Publishing, pp. 199-234.

YU, T.-Y. and YU, T.-K. 2017. The Moderating Effects of Students' Personality Traits on Pro Environmental Behavioral Intentions in Response to Climate Change. Int. J. Environ. Res. Public Health, 14: 1472.

Contact information

Dorota Anderlová: xanderl1@mendelu.cz

Michal Pšurný: xpsurny@mendelu.cz 